\title{
The Asymmetric Impact of Oil Price and Electricity Consumption on Economic Growth: Evidence from Nigeria
}

\author{
Adedayo Emmanuel LONGE, ${ }^{1}$ \\ Taiwo Matthew ADEKOYA, ${ }^{2}$ Caleb Olugbenga SOYEMI, ${ }^{3}$ \\ David Adeiza AGBANUJI, ${ }^{4}$ Idowu Jacob ADEKOMI ${ }^{5}$ \\ ${ }^{1,2}$ Centre for Petroleum, Energy Economics and Law (CPEEL), University of Ibadan, Nigeria \\ ${ }^{3,5}$ Department of Economics, Olabisi Onabanjo University, Ago-Iwoye, Ogun State, Nigeria \\ ${ }^{4}$ Energy Economics, Management and Policy, Emerald Energy Institute, Uniport \\ ${ }^{1}$ longeemmanuel28@gmail.com, ${ }^{2}$ adekoyatm@gmail.com, \\ ${ }^{3}$ caleb.soyemi@oouagoiwoye.edu.ng, ${ }^{4}$ agbanuji@gmail.com, ${ }^{5}$ adekomiidowu@gmail.com
}

\begin{abstract}
The study examines the asymmetric impact of oil price and electricity consumption on economic growth in Nigeria between 1981 and 2018 using the Non-Linear Autoregressive Distributed Lag (NARDL) model. Results reveal that falling and increasing oil prices as well as gross capital formation affect economic growth in Nigeria negatively and significantly in the short-run, while electricity consumption affects economic growth positively and significantly in the short-run. In the long-run, the impact on economic growth of negative changes in oil price is negative and insignificant, while positive changes in oil price have a positive but insignificant impact on economic growth. The impact on the economic growth of electricity consumption remains positive but insignificant while that of gross capital formation is positive and significant. The results suggest that both in the short and the long run positive changes in oil price have greater impact on the economic growth than negative oil price changes. Capital formation is a significant determinant of Nigerian economic growth both in the short and the long run.
\end{abstract}

Keywords: oil price, electricity consumption, economic growth, NARDL JEL Classification: C22, O40, Q31, Q43

\section{Introduction}

Electricity is one of the significant inputs considered by investors and households in economies. It has been recognized to be important for social and economic development in Africa and as a factor for improving economic activities (International 
Energy Agency (IEA), 2002; Constantini and Martini, 2010). Oil price is identified as one of the factors that drive electricity consumption in an economy, leaving its impact on economic growth unstable. Oil price impact varies across economies depending on the demand or supply side they belong to. In petroleum exporting countries, the price of petroleum has been observed to influence the nations' economic growth positively (Farzanegan and Markwardt, 2009; Timilsina, 2015). In contrast, a negative relationship has been observed in this respect in oil importing countries (Lardic and Mignon, 2006; Jayaraman and Choong, 2009). The variation in impact is due to what the price of petroleum means to different economies. To petroleum-exporting nations, petroleum price is considered as an income, while to petroleum-importing nations, it is considered as an expenditure.

The Nigerian electricity sector has been known for its deficient electricity supply, leaving the nation exposed to high costs of energy despite its endowment in energy resources. This state of affairs can be traced to low capital investment in public utilities (Paul, Albert, and Adeiza, 2015). According to Iwayemi (1998), deficiencies in the electricity sector prompted capital release with limited government intervention. The liberalization policy therefore urged the sale of the power-generating companies and a $60 \%$ sale of government shares in the power distribution companies in 2013 (Nwachukwu, 2015; MBendi, 2016; NERC, 2017). However, the electricity shortage problem persists, causing more consumption of the conventional energy (fossil fuel products) as an alternative source whose cost is indirectly determined by the movement in oil prices.

There is limited literature on the price of petroleum, electricity use, and GDP. Among the few studies - such as Sarwar et al. (2017) and Shahbazet al. (2017) on the connection between oil price, electricity use, and economic growth -, panel data are commonly used, while others are country- and variable-specific, including the ones on the Nigerian economy (Akinlo, 2009; Shahbazet al., 2017; Sarwar, Chein, and Waheed, 2017).

On the methodological front, the Linear Autoregressive Distributed Lag (ARDL) method developed by Pesaran et al. (2001) has been commonly employed in literature in studies on oil price and growth for time series and cross-sectional data analysis (Shahbaz and Dube, 2012; Shahbazet al., 2017). However, in the Nigerian context, we acknowledge that the reviewed existing literature has concentrated on the nexus that exists between oil price and GDP as well as between electricity use and GDP, with diverse findings (among others: Akinlo, 2009; Omitogun, Longe, and Shehu, 2018; Iwayemi and Babajide, 2011; Nwanna and Eyeday, 2016). To the best of our knowledge, none of the previous studies has considered the asymmetric model of Shin et al. (2014) on examining the effect of asymmetric petroleum price and electricity consumption on economic growth by taking a partial sum decomposition of petroleum price and incorporating the break periods effect. The study considered oil price and electricity consumption as input factors to be 
considered for production and that have relationship with the Nigerian economic growth.

The scope of the paper is sectioned as follows: a detailed review of the literature is presented in the next section, while section three provides the theoretical and methodological framework. Section four presents the results in line with the objectives of the study, and section five provides detailed concluding remarks from the results of the study.

\section{Literature Review}

Theoretically, there is no unified explanation on the link between the price of petroleum and GDP. Therefore, several theories were born in the literature to determine this link. The so-called Dutch disease is one of the theories. It explains the problems that happen in case there is a rise in the production of raw materials (crude oil in relative to this study) which leads to decrease in other sectors of an economy. Overreliance on raw material affects the growth of an economy; for a country to develop, it must produce finished goods. An economy must not depend on excess import of goods and services. The Dutch disease can lead to a wide gap between the rich and the poor in Nigeria. The realization of crude oil in Nigeria has led to overreliance on raw material, excess imports of finished goods, increase in wages, and income inequality. Nigeria as a country forgoes agriculture and shifts attention to crude oil due to its large deposits in the Niger Delta area. Crude oil has been the main source of revenue for Nigeria since its discovery, and this is a curse because there is a persistent decline in petroleum price.

The neoclassical growth model authored by Solow and Swan (1956) states that economic growth results from three (3) factors: technology, capital, and labour. While the contribution of labour and capital to economic growth is restricted, technology has limitless contribution to the growth of an economy. Recently, capital availability has been a major constraint to improvement in economic activities as many investors are panicking about possibilities of making loss in the Nigerian environment. However, in order to increase capital level and accessibility, efforts have been concentrated on increasing banks' loan-to-deposit ratio from $60 \%$ to $65 \%$ by the Central Bank of Nigeria (CBN) while considering capital formation as an incentive to the growth of the economy.

In this study, we partitioned related empirical studies into two parts: electricity/ energy use and economic growth, oil price and economic growth. 


\section{Electricity/Energy Consumption and Economic Growth}

Among studies in developed countries such as the United States, Kraft and Kraft (1978) pioneered their study on the causal link that exists between electricity use and GNP and noted the existence of a unidirectional causal relationship. Akrarca and Long's (1980) study on the same subject observed no causal relationship. Ghosh (2002) noted the absence of long-run connection between energy use and growth and a unidirectional causal link from energy use to growth.

Using bounds and causality tests in their study on per capita energy use and economic growth performed in developing and emerging economies, for 17 countries between 1971 and 2001, Wolde-Rufae (2006) observed a long-term cointegration among the variables for six nations (Nigeria, Cameroun, Ghana, Zimbabwe, Senegal, and Zambia) and causal relationship running from economic growth to energy use in three countries. Squalli (2007) noted for OPEC nations in the long term a cointegrating link and bi-directional nexus among economic growth and electricity use. Jamil and Ahmad (2010) concluded from their study that in Pakistan economic planning exercise, electricity production, and management should be incorporated.

Belke et al. (2011) asserted for 25 OECD countries based on their findings that a cointegration and a bidirectional relationship exists among GDP, energy price, and energy use. Based on their findings in Pakistan, Shahbaz and Dube (2012) established a positive effect of coal use, capital use, and labour participation rate on economic growth between 1972 and 2009. Enu and Havi (2014) in Ghana noted a positive effect of electricity use on economic growth in the long term, while in the short term the impact was found negative. They further confirmed a causality link going from electricity use to economic growth. Relying on results from a sectoral analysis in Pakistan, Tang and Shahbaz (2013) hold that electricity use Granger causes manufacturing and service sectors, while there is no direction of causality between electricity use and agricultural sector. Using data spanning between 2000 and 2012, Kasperowicz (2014) confirmed in Poland a bidirectional link between capital formation, electricity use, and economic growth. Dagon (2015) also confirmed a unidirectional causal link between electricity generated and economic growth in Turkey. In his study carried out in 18 Sub-Saharan African countries between 1980 and 2011, Fatai's (2014) findings testify to a steady longterm connection between energy use and economic growth. However, the causal relationship varies across the sub-regions. Sama and Tah (2016) used GMM and established that petroleum and electricity consumption impacted positively on economic growth in Cameroon.

Shahbaz et al. (2017) observed a bidirectional link between electricity use and economic growth in both high and upper-middle income countries, East Asia Pacific countries, OECD countries, and Central Asia and European countries in 
the long run. In contrast, one-way causality link running from economic growth to electricity use was noticed in South Asia, the Middle East, low-middle income and North African countries. For 75 net-energy-importing countries, Esen and Bayrak's (2017) study shows a significantly positive connection between energy use and economic growth. Samu et al's (2019) study in Zimbabwe showed that electricity use positively and significantly affects economic growth.

Akinlo (2009) employed the Hodrick-Prescott (HP) filter in examining the causal link between energy use and economic growth. The findings confirmed a one-way link moving from electricity use to economic growth in Nigeria. Odularu and Okonkwo (2009) noted that energy use positively affects economic growth. Nwankwo and Njogo (2013) observed that electricity use, industrial production, and economic development in Nigeria are positively connected through the electricity generated and consumed by the sector. Ogundipe and Apata's (2013) study results show a two-way causality nexus between electricity use and economic growth in Nigeria. Oyaromadeet al. (2014) confirm no causal link between energy use and economic growth in Nigeria. Ogunjobi (2015) observed a significant positive impact of electricity consumption on industrial outputs in Nigeria. Bernard and Adenuga's (2016) study attests to a long-term significant connection between energy use and industrial productivity in Nigeria.

\section{Oil Price and Economic Growth}

Mory (1993) in the United States confirmed that rise in the price of petroleum caused by reduction in economic activities and decreases in the price have no relationship with the economy. In European Countries, Lardic and Mignon's (2006) findings reject standard cointegration between petroleum price and GDP, but they noted an asymmetric cointegration between petroleum price and GDP in the majority of the countries considered. While focusing on the asymmetric link in oil exporting countries, Mehrara (2008) noted that negative oil shocks negatively affect the growth of the economies. Jayaraman and Choong's (2009) causal investigation on the sudden changes in the price of petroleum and economic growth revealed a one-way causality link running from international reserves and petroleum price to economic growth in Pacific Island Countries. Farzanegan and Markwardt (2009) found economic growth response in Sub-Saharan Africa to be positive for high oil prices due to Nigeria's dominance as an oil exporter in the region and a major determinant of the economy.

Timilsina's (2015) study using Computable General Equilibrium (CGE) revealed that oil price increase causes GDP in emerging nations, i.e. in China, India, and Thailand, to decline. Considering Venezuela, Saudi Arabia, Kuwait, and the United Arab Emirates, Ftiti et al. (2016) argued that the surprises to the price of petroleum directly affect the economic growth in the countries during financial turmoil. 
Using the OLS method, Jahangir and Dural (2018) showed a positive significant impact of crude oil price on the growth of the Caspian Sea region's economy. They also confirmed a one-way causality link running from crude oil price to economic growth. Benliet al's (2019) asymmetric study on oil price in Turkey's economy revealed that positive petroleum prices negatively and significantly influence economic growth in the long run. Their study noted that output negative response to positive changes in the price of petroleum is greater than that of the negative changes. In their study on the impact of oil price and economic growth of some low-income oil importing Sub-Saharan African countries, Akinsola and Odhiambo (2020) revealed that negative oil price changes positively and significantly impact the economic growth, while the rises in the price of petroleum have a negative and significant effect.

Iwayemi and Babajide (2011) in their study on Nigeria concluded from their findings that shock in oil price affects the economy's output when it is negative. Adeniyi et al. (2011) ascertained that the surprises to the petroleum price do not add up to the amount to be considered significant in the movement of macroeconomic aggregates. Nwanna and Eyeday's (2016) study revealed that petroleum price volatility portends an adverse effect on the growth of the Nigerian economy. Ogboru, Rivi, and Park's (2017) study is in contrast with Nwanna and Eyeday (2016), who state that the price of petroleum exerts a positive effect on the growth of the Nigerian economy. Omitogun et al. (2018) concluded from their study that the price of petroleum and public income variations are robust drivers of the Nigerian economic growth. Adedeji et al. (2018) noted that variations in the price of petroleum (positive or negative) significantly affect economic growth in Nigeria, while in Angola only negative oil price is significant to economic growth. Yakubu and Akanegbu's (2019) findings revealed that the price of petroleum and Nigerian economic growth are connected in the long term, but there is no evidence of causal relationship. However, it is noted that the literature review shows a diverse picture with different findings stemming from the adoption of methods, scope and objectives of the studies. We, therefore, add to the existing literature by considering oil price and electricity consumption as a factor input in the neoclassical production model applying the NARDL model to investigate the effect on the economic growth in the Nigerian context.

\section{Theoretical and Methodological Framework}

This paper examines the impact of electricity use on economic growth in Nigeria while integrating asymmetric petroleum price into the modified production function by Shahbaz et al. (2017). The hike in the price of petroleum is responsive to both petroleum importing and exporting nations (Shahbaz et al., 2017). Shahbaz 
et al. (2017) noted that oil price impacts on economic activities on both the supply and demand side. From the viewpoint of supply, oil price is considered as a factor of production which affects the cost of production as it fluctuates and leads firms or industries to lower outputs. On the demand side, the effect of petroleum price is not limited only to its usage but also includes investment activities. A rise in the price of petroleum production, reduced real wage rate as demand for labour declines due to decline in economic activities. As further noted by Shahbaz et al. (2017), oil price is an input cost that may reduce investment activities through its impact on exchange rate, inflation rate, and energy costs, which finally leads to a declining economic growth. However, for this study, we consider oil price as a factor affecting both the demand side (electricity consumed) and the supply side (revenue) of the economy in Nigeria. Therefore, we modified the augmented production function by Shahbaz et al. (2017) by retaining electricity consumption, oil price, and capital as the factors that determine the Nigerian economic growth. The model is specified as:

$$
Y_{t}=f\left(E_{t}, O_{t} K_{t}\right),
$$

where $E, O$, and $K$ are electricity use, oil price, and capital formation resp., while $Y$ is the output, and $t$ is the time period.

Shahbaz and Lean (2012) contended that specifying a model in a log-linear form increases the efficiency and reliability of empirical evidence provided by the model comparative to a simple linear specification. To achieve this assertion, the variables in Equation 1 are transformed into a natural logarithm form and are modelled as:

$$
\ln Y_{t}=\alpha_{0}+\beta_{1} \ln E_{t}+\beta_{2} \ln O_{t}+\beta_{3} \ln K_{t}+\mu_{t},
$$

where $\ln Y_{t}, \ln O_{t}, \ln K_{t}$, and $\mu_{t}$ are the natural $\log$ of real GDP per capital (i.e. economic growth), oil price, gross fixed capital formation per capita, and a whitenoise error term resp.

As the study focuses on the effect of electricity use and of petroleum price asymmetries' on economic growth, the Non-Linear Auto-Regressive Distributed Lag (NARDL) model of Shin et al. (2014) is adopted. The model is an asymmetric modification of the symmetric linear model of Pesaran et al. (2001). Following Pesaran et al's (2001) symmetric linear ARDL model, the conditional error correction model of the link between electricity use, oil price symmetry, and economic growth is modelled as: 


$$
\begin{aligned}
\Delta \ln Y_{t}=\alpha_{0}+ & \theta_{1} \ln Y_{t-i}+\theta_{2} \ln E_{t-i}+\theta_{3} \ln O_{t-i} \theta_{4} \ln K_{t-i}+\sum_{k=1}^{n_{1}} \alpha_{1 k} \Delta Y_{t-i}+\sum_{k=0}^{n_{2}} \alpha_{2 k} \Delta E_{t-i} \\
& +\sum_{k=0}^{n_{3}} \alpha_{3 k} \Delta O_{t-i}+\sum_{k=0}^{n_{4}} \alpha_{4 k} \Delta K_{t-i}+\mu_{t}
\end{aligned}
$$

where $\alpha_{1}, \alpha_{2}, \alpha_{3}, \alpha_{4}$ are the long-term coefficients of the parameters, while $\theta_{1}, \theta_{2}, \theta_{3}$, and $\theta_{4}$ are the short-term coefficients of the parameters; $n_{1}-n_{4}$ are the optimal lag lengths of the parameters automatically selected using the Akaike Information Criterion (AIC); $\alpha_{0}$ is the model intercept; $\mu_{t}$ remains the whitenoise error term at time $t$.

To mirror an asymmetric impact, Shin et al. (2014) developed a NARDL model that permits the partial decompositions of a parameter to evaluate the long-term and short-term effect.

$$
\begin{aligned}
& O_{t}^{-}=\sum_{j=1}^{t} O_{t}^{-}=\sum_{j=1}^{t} \max \left(\Delta_{O_{j}}, 0\right) \\
& O_{t}^{+}=\sum_{j=1}^{t} O_{t}^{+}=\sum_{j=1}^{t} \max \left(\Delta_{O_{j}}, 0\right)
\end{aligned}
$$

From equations 4 and $5, O_{t}^{-}$and $O_{t}^{+}$represent the negative and positive fluctuations, resp., in petroleum price. These parameters are thus incorporated into the linear ARDL model to replace oil price, therefore transforming the model into a NARDL model. The model is rewritten as:

$$
\begin{aligned}
\Delta \ln Y_{t}=\alpha_{0}+ & \theta_{1} \ln Y_{t-1}+\theta_{2} \ln E_{t-1}+\theta_{3}^{+} \ln O^{+}{ }_{t-1}+\theta_{3}^{-} \ln O^{-}{ }_{t-1}+\theta_{4} \ln K_{t-1} \\
& +\sum_{k=1}^{n_{1}} \alpha_{1 k} \Delta Y_{t-k}+\sum_{k=0}^{n_{2}} \alpha_{2 k} \Delta E_{t-k}+\sum_{k=0}^{n_{3}} \alpha_{3 k}^{+} \Delta O^{+}{ }_{t-i}+\sum_{k=0}^{n_{4}} \alpha_{3 k}^{-} \Delta O^{-}{ }_{t-i} \\
& +\sum_{k=0}^{n_{5}} \alpha_{4 k} \Delta K_{t-1}+\mu_{t}
\end{aligned}
$$

$\alpha_{3,}^{+}, \alpha_{3,}^{-}$are the long-term coefficients of negative and positive fluctuations in the price of petroleum, while $\theta_{3}^{+}, \theta_{3}^{-}$are the short-run coefficients of positive and negative changes in oil price. Other denoted parameters remain as defined earlier. 
However, to account for structural breaks, a dummy variable $\sum_{r=1}^{s} B_{r} D u m m y_{r t}$ to explain the breaks identified in the study is incorporated into Equation 6. The dummy variable takes the value of 0 before the structural break date and of 1 after the structural break occurs. The model is respecified as:

$$
\begin{aligned}
\Delta \ln Y_{t}=\alpha_{0}+ & \sum_{k=1}^{n} \alpha_{1 k} \Delta Y_{t-k}+\sum_{k=0}^{n} \alpha_{2 k} \Delta E_{t-k}+\sum_{k=0}^{n} \alpha_{3 k}^{+} \Delta O^{+}{ }_{t-i}+\sum_{k=0}^{n} \alpha_{3 k}^{-} \Delta O^{-}{ }_{t-i} \\
& +\sum_{k=0}^{n} \alpha_{4 k} \Delta K_{t-1}+\theta_{1} \ln Y_{t-1}+\theta_{2} \ln E_{t-1}+\theta_{3}^{+} \ln O^{+}{ }_{t-1}+\theta_{3}^{-} \ln O^{-}{ }_{t-1} \\
& +\theta_{4} \ln K_{t-1}+\sum_{r=1}^{s} B_{r} \text { Dummy }_{r t}+\mu_{t}
\end{aligned}
$$

The study employed macroeconomic data spanning between 1981 and 2018. The variables are real GDP per capita (constant 2010 US\$), which proxied economic growth (GDP), oil price (O), US\$ obtained from BP Statistical Bulletin (2019), gross fixed capital formation at constant 2010 US\$ (GCF), and electricity consumption (EC)-electricity consumed in kW per capita. Aside from OP, all other data were obtained from the World Development Indicator (WDI) (2019).

\section{Results}

\subsection{Correlation Matrix Test}

The correlation test was done to establish the kind of link that exists among the variables, whether they are highly correlated or not, and to ensure there was no multicollinearity problem. The correlation matrix in Table 1 shows that the variables studied are positively and significantly correlated. A strong correlation exists between GDP and oil price.

Table 1. Correlation matrix test results using raw data

\begin{tabular}{lcccc}
\hline & GDP & OP & E & GCF \\
\hline GDP & 1 & & & \\
OP & $0.875^{* *}$ & 1 & & \\
E & $0.864^{* *}$ & $0.815^{* *}$ & 1 & 1 \\
GCF & $0.924^{* *}$ & $0.761^{* *}$ & $0.704^{* *}$ & Source: authors' computation
\end{tabular}

** connotes significant level at $5 \%$ 


\subsection{Descriptive Statistics}

The nature of the variables over the period covered is captured in the descriptive statistics results. The average values of the variables, kurtosis, and the JarqueBera results are considered in this study. From the results, the study confirms that the average values of the variables included in the model range within the maximum and minimum values. This, therefore, establishes that the trend of the variables over the period studied is not an extreme one. The kurtosis result confirms that the distribution is platykurtic (flat relative to the normal). The Jarque-Bera statistics verified that the variables are abnormally distributed as the values of their probability are less than $5 \%$ level of significance (see Table 2).

Table 2. Descriptive statistics results (raw data)

\begin{tabular}{lcccc}
\hline & GDP & O & E & GCF \\
\hline Mean & 1708.336 & 42.94185 & 104.46884 & $3.34 \mathrm{E}+10$ \\
Maximum & 2563.14 & 111.6697 & 156.733 & $7.46 \mathrm{E}+10$ \\
Minimum & 1151.126 & 12.71566 & 50.87268 & $9.57 \mathrm{E}+09$ \\
Kurtosis & 1.65536 & 2.864166 & 1.906792 & 1.911192 \\
Jarque-Bera & 4.895887 & 7.234318 & 2.217986 & 5.439937 \\
Probability & 0.086471 & 0.026859 & 0.329891 & 0.065877 \\
Observations & 38 & 38 & 38 & 38 \\
\hline
\end{tabular}

Source: authors' computation

\subsection{Unit Root Test}

To avoid having a spurious result and to verify if the variables are mean regressing in the long term, the study considered testing for the presence of unit root problem among the variables. To do this, the Phillips-Perron (PP) test by Phillips and Perron (1988) and the Augmented Dickey Fuller (ADF) test by Dickey and Fuller (1979) were adopted. The variables are tested at levels and after first differencing. The result presented in Table 3 confirmed that the variables have unit root problem as they are stationary after first differencing. This result suggests that the variables are not mean regressing in the long term. 
Table 3. Unit root test

\begin{tabular}{|c|c|c|c|c|c|}
\hline & ADF & $\mathbf{P P}$ & & ADF & PP \\
\hline \multicolumn{4}{|c|}{ Level } & \multicolumn{2}{|c|}{$1^{\text {st }}$ Difference } \\
\hline GDP & -2.356 & -2.315 & $\mathrm{D}(\mathrm{GDP})$ & $-4.528 * *$ & -4.524 ** \\
\hline $\mathbf{O}$ & -2.233 & -2.233 & $\mathrm{D}(\mathrm{OP})$ & $-5.190 * *$ & -5.141 ** \\
\hline $\mathbf{E}$ & -2.749 & -2.883 & $\mathrm{D}(\mathrm{E})$ & $-7.697 * *$ & $-7.882 * *$ \\
\hline GCF & $-3.902 * *$ & $-3.883^{* *}$ & $\mathrm{D}(\mathrm{GCF})$ & $-5.378^{* *}$ & $-4.763 * *$ \\
\hline CV1\% & -4.235 & & & & \\
\hline $5 \%$ & -3.540 & & & & \\
\hline $10 \%$ & -3.202 & & & & \\
\hline
\end{tabular}

Source: authors' computation

** implies significance level at 5\%, CV denotes critical values

\subsection{Non-Linear Autoregressive-Distributed Lag (ARDL) Bounds Test}

The study follows Pesaran et al's (2001) guide on ARDL bounds test for its longterm cointegration estimation. The F-statistics is compared with the upper [I(1)] and lower $[\mathrm{I}(0)]$ bounds class. From the results presented in Table 4, the F-statistic value is above both the upper and lower bound values at a significance level of $5 \%$. Due to this, it is concluded that an asymmetric long-term cointegrating link exists between the variables used in the study.

Table 4. NARDL Bounds Test Results

\begin{tabular}{cccc}
\hline F -Statistics & K & $\mathbf{I}(\mathbf{0})$ & $\mathbf{I ( 1 )}$ \\
\hline $9.032^{* *}$ & 4 & 3.47 & 4.57 \\
\hline
\end{tabular}

Source: authors' computation

* * implies significance level at 5\%; I(0) and I(1) denote the upper bound and lower bound class respectively 


\subsection{Bai-Perron Structural Break}

To identify the break ranges in this study, the Bai-Perron (2003) test is chosen for the purpose. The test helps identify significant periods that may affect the model. The test identified 5 periodic breaks including 1987, 1992, 2004, 2009, and 2014. In 1987, oil price tumbled following the previous year's unfaithful act of Saudi Arabia in adhering to their own quota of oil production cut at $30 \mathrm{mb} / \mathrm{d}$ agreed by the cartel, therefore leading to a dispute within OPEC members (Baffes, Kose, Ohnsorge, and Stocker, 2015). The impact of the first Gulf War in 1990 leads to the break identified in 1992, when a slow growth was recorded in oil price. In 2004, oil price started gaining momentum on the back of the rise in the demand for crude oil as China's demand for crude oil exceeded $1 \mathrm{mb} / \mathrm{d}$ (Baffeset al., 2015). The break identified for 2009 was a result of the severe contraction in global demand for commodities, which led the world to a great recession (Baffeset al., 2015). The 2014 break identified by the test was a period of slowdown in global economic activities, but it mostly came from the demand and supply surprises in the petroleum market (Baffeset al., 2015). The break periods are included in the model as dummy variables and connoted in the estimation as B1, B2, B3, B4, and B5 in order to identify significant break periods. Results are presented in Table 5.

Table 5. Bai-Perron (2003) structural break dates

\begin{tabular}{cc}
\hline Variable & Identified Break Periods \\
\hline Oil Price & 1987 \\
\hline & 1992 \\
\hline & 2004 \\
\hline & 2009 \\
\hline
\end{tabular}

Source: authors' compilation

\subsection{NARDL Estimation}

The study estimated the parameters using an Akaike Information Criteria (AIC) automatic lag selection. The automatic lags selected by AIC are $[4,4,1,3,3]$ for $G D P, E C, O^{-}, O^{+}$, and $G C F$. We reported the long-term and short-term estimation of the parameters and found a long-term cointegration existence between the variables at $5 \%$ significance level. Following the lag selected, electricity use impacted positively on economic growth in Nigeria and was significant at $5 \%$ in the short term. The result confirms that $1 \%$ change in electricity use influences economic growth by $13.7 \%$ in the short term. This means that the electricity consumed 
per head in the Nigerian economy is growth-driven in the short term. Recently, the country has been placing emphasis on promoting awareness about the use of energy efficient products and on adopting a conservative behaviour towards the use of energy in the environment. Therefore, the policies will increase the growth of the economy. The short-term impact of negative as well as positive shocks to the petroleum price have a significantly negative effect at $5 \%$ on the economic growth in Nigeria. $1 \%$ positive and negative shocks to the price of petroleum contracts the economic growth of Nigeria by $17.8 \%$ and $8.1 \%$, respectively, in the short term. Nigeria largely depends on oil as its mainstay. Surprises to the price of petroleum in the short term affect both the supply and demand side of the economy. While focusing on the supply side, it can be deduced from the results that the economic growth of Nigeria is expected to contract as negative shocks to the price of petroleum may favour producers since the price of petroleum products may decrease, therefore reducing cost of production and increasing profit making (this explains the demand side effect of the negative changes). However, as oil price decreases, government revenue contracts. This may initiate the need to review budgetary plans as experienced in the recent oil price shocks caused by the Covid-19 pandemic, which influenced the review of budget oil price from $\$ 59 \mathrm{pb}$ to a third review of $\$ 28 \mathrm{pb}$ from a first and second review of $\$ 30 \mathrm{pb}$ and $\$ 25 \mathrm{pb}$ respectively. On the other hand, positive shocks to the petroleum price favour the government as the revenue increases but are detrimental to investors or producers as they increase the cost of production through rise in the price of petroleum products. This has been recently evidenced by the rising prices of PMS from N125/litre to N143.80/litre for the month of July 2020. This increase is expected to impact on production activities in the economy as many of the producers depend on oil products as an alternative means of generating electricity for their activities. As activities are slowed down, economic growth is predicted to decline. The effect of gross capital formation on Nigerian economic growth in the short run is negative and significant at $5 \%$. As gross capital formation changes by one percent, Nigerian economic growth declines by $10 \%$ in the short term. This means that capital accessibility by investors in Nigeria is not sufficient enough to increase the Nigerian economic growth in the short term. The error correction model coefficient is negative and significant at $5 \%$. This means that the independent variables are capable of correcting about $142 \%$ deviation of economic growth from the short-term equilibrium to the long-term equilibrium. The result also suggests an oscillatory convergence in the long term and in real time it means that a stable positive trend in oil price and electricity consumption will correct disequilibrium in economic growth within a minimum of 1 year and 4 months. After considering the break periods in the model, it was confirmed from the estimation that the break period of 1987 positively but insignificantly affects Nigerian economic growth. The 1992 and 2009 break periods impact negatively and significantly on Nigerian economic 
growth. The 2004 petroleum price break impact on economic growth was positive and significant, while the 2014 petroleum price break negatively but insignificantly affected Nigerian economic growth.

The correctness of the model specification was tested using diagnostic test. From the results, the Ramsey RESET test validates that the model is correctly specified as its F-statistic probability value is greater than $5 \%$. The model is free of serial correlation and is homoscedastic. The CUSUM test confirmed the stability of the model; however, it is unstable considering the CUSUM test model.

In the long-term, the impact of electricity use on economic growth is positive but insignificant. This implies that as electricity consumption increases by $1 \%$ in the long term, it insignificantly increases the growth of the economy by $11.8 \%$. Albeit electricity is considered a significant catalyst of economic growth in the Nigerian context, the consumption pattern of electricity contributes to the Nigerian economic growth in the long run, but not towards the expected growth dimension. Negative changes in oil price show a negative but insignificant effect on economic growth in the long term. Results reveal that as oil price declines by $1 \%$ in the long term, the Nigerian economic growth declines by $8.8 \%$, which is, however, insignificant. Although Nigeria's revenue reacts negatively to negative changes in oil price, diversification strategies adopted by the government in recent years towards its revenue base may render the effect of shocks to oil price on the economic growth insignificant in the long term. Positive shocks to the price of oil in the long term show that Nigeria's economic growth increases by $19.5 \%$ for every $1 \%$ positive fluctuation in oil price. This implies that as the petroleum price trends positively in the long term, the government's capacity to finance other strategic sectors of the economy increases and positively impacts on the economic growth of Nigeria. However, the mismanagement factor may render the positive trends in the effects of petroleum price on economic growth positively insignificant in the long term. In the long run, gross capital formation will positively and significantly (at 5\% significance level) impact Nigerian economic growth. $1 \%$ change in gross capital formation increases economic growth by $30.3 \%$ in the long term. Policies on capital accessibilities in the Nigerian economy (e.g. the increase of loan-to-deposit ratio by banks from 60 per cent to 65 per cent and fiscal stimulus to support businesses during the recent pandemic) are expected to increase production activities and promote the economic growth of Nigeria in the long term. 
Table 6. NARDL short-term and long-term estimation

Selected Model: ARDL $(4,4,1,3,3)$

\section{Short-Run Estimates}

Nigeria

Variables

C

Trend

$\Delta \ln E C_{t-1}$

$\triangle \ln E C_{t-2}$

$\Delta \ln E C_{t-3}$

$\Delta \ln E C_{t-4}$

$\Delta \ln O^{+}{ }_{t-1}$

$\Delta \ln {O^{-}}_{t-1}$

$\Delta \ln O^{-}{ }_{t-2}$

$\Delta \ln O^{-}{ }_{t-3}^{-}$

$\triangle \ln G C F_{t-1}$

$\triangle \ln G C F_{t-2}$

$\Delta \ln G C F_{t-3}$

B1

B2

B3

B4

B5

ecm ${ }_{t-1}$

$-0.314(0.031) * *$

$0.001(0.001) * *$

$0.087(0.044)^{* * *}$

$-0.182(0.039)$ * *

$-0.053(0.056)$

$0.137(0.038) * *$

$-0.081(0.017)^{* *}$

$-0.040(0.028)$

$-0.168(0.039)$ **

$-0.178(0.032)$ * *

$0.161(0.028)$ **

$-0.159(0.039)$ **

$-0.100(0.026)$ **

0.005(0.012)

$-0.040(0.010)^{* *}$

$0.129(0.017)$ **

$-0.041(0.006)^{* *}$

$-0.011(0.007)$

$-1.429(0.174)$ **

\section{Diagnostic Test}

Ramsey RESET

$1.248[0.2723]$

Serial Correlation

$3.456[0.0722]$

Heteroskedasticity

$1.311[0.2862]$

CUSUM Test

Stable

CUSUMQ Test

Unstable

\section{Long-Run Estimates}

$\ln E C_{t}$

$0.118(0.142)$

$O_{t}^{-}$

$-0.088(0.064)$ **

$\mathrm{O}_{t}^{+}$

$0.195(0.173)$

$\ln G C F$

$0.303(0.047)$ **

Source: compiled by the authors

$* *$, *** connotes significance level at 5\% and 10\% respectively. The parenthesis ( ) denotes the std. error of the estimation. B1, B2, B3, B4, and B5 are the structural 
break periods identified by the Bai-Perron test and incorporated in the estimation process. [ ] are probability values for the diagnostic F-statistic values

\section{Concluding Remarks}

Adopting Shin et al's (2014) NARDL model, this paper investigates the asymmetric effect of the price of oil and electricity consumption on Nigerian economic growth. The study takes a fractional sum decomposition of oil price. Study pre-estimation results suggest that the variables are stationary after first differencing, which implies that there is a unit root problem among the variables. Due to this unit root problem, the study adopted the NARDL bounds test to assess the long-run cointegration among the variables. Results revealed that a $5 \%$ significant long-term cointegrating link exists between the variables. After confirming the cointegrating link, we further assess the long-term and short-term impact of oil price asymmetry and electricity consumption on economic growth. Results show that gross capital formation, electricity use, and negative as well as positive shocks to the oil price significantly affect the economic growth, only electricity use having a positive effect. In the long run, the positive shocks to the price of petroleum have a positive impact, while negative shocks have a negative impact on economic growth although insignificant. Electricity use positively but insignificantly affects economic growth. However, gross capital formation shows the possibility of having a longterm significant positive effect on the economic growth of Nigeria. Our findings provide a support to the theoretical Dutch Disease argue on the Nigerian economy. Notably, starting out from Solow and Swan's (1956) framework on the importance of capital flow as a catalyst to the growth of an economy, our study supports that capital formation is a significant factor of economic growth. The study findings corroborate Benli et al. (2019) in that the effect of positive shocks to the price of petroleum is greater than the impact of the negative shocks. However, our results are in contrast with the findings of Adedeji et al. (2018) that while measuring negative and positive shocks to petroleum prices as a determinant of economic growth in Nigeria, the significance level differs in the short and the long term.

Comparing our findings with those of studies on developed countries, such as Belke et al. (2011) or Kasperowicz (2014), carried out in OECD countries and Poland deviations can be found. These deviations are results of the difference in the focus of the studies. The studies examined the causal impact between electricity consumption and economic growth, while we estimate the short-run and longrun impact of electricity consumption on economic growth in Nigeria. Compared to studies on countries being at the same level of development as Nigeria - such as Fatai's (2014) study on Sub-Saharan Africa, Enu and Havi's (2014) study on electricity consumption and economic growth in Ghana -, our findings corroborate 
their study in that for developing countries, including Nigeria, the long-term connection between electricity consumption and economic growth is positive, while this relationship is positive and significant in the short run. We conclude from our findings that positive shocks to the price of petroleum have a greater impact on the Nigerian economic growth in the short as well as long term than negative shocks have. Capital formation should be considered as a growth catalyst in the government's long-term and short-term economic growth plans. However, major policy implications should be that the government, at all levels of the economy, should work towards increasing energy efficiency in their jurisdictions and encourage electricity consumers to adopt energy conservation policies. Nigeria should also seek to reduce its dependency on crude oil to avoid the consequence of the shocks to oil price on the economic growth of the country. This can be done by diversifying excess crude earnings to other strategic sectors such as agricultural production or industrial metals, among others, which have more economic cost power. Promoting such sectors will help mitigate the risk imposed by the unstable nature of the price of petroleum on the economic growth of Nigeria.

\section{References}

Adedeji, A.; Ahmed, F.; Muhammed, M. (2018). Empirical evidence of oil price shocks and oil economy asymmetric nexus: The case of Angola and Nigeria. Advances in Social Science Research Journal 5(6): 17-32.

Adeniyi, O.; Oyinlola, A.; Omisakin, O. (2011). Oil price shocks and economic growth in Nigeria: Are thresholds important? OPEC Energy Review 35(4): 308333. DOI: https://doi.org/10.1111/j.1753-0237.2011.00192.x.

Akarca, A. T.; Long, T. V. (1980). Relationship between energy and GNP: A reexamination. The Journal of Energy Development 5(2): 326-331. DOI: https://www. jstor.org/stable/24806899.

Akinlo, A. E. (2009). Electricity consumption and economic growth in Nigeria: Evidence from cointegration and co-feature analysis. Journal of Policy Modeling 31(5): 681-693. DOI: https://doi.org/10.1016/j.jpolmod.2009.03.004.

Al-mulali, U.; Che Sab, C. N. (2012). The impact of energy consumption and CO2 emission on the economic growth. Energy 39(1): 180-186. DOI: https://doi. org/10.1016/j.energy.2012.01.032

Baffes, J.; Kose, A.; Ohnsorge, F.; Stocker, M. (2015). The great plunge in oil prices: Causes, consequences, and policy responses. Washington, D.C., the United States: The World Bank Group Policy Research Note.

Bai, J.; Perron, P. (2003). Computation and analysis of multiple structural change models. Journal of Applied Econometric 18(1): 1-22. DOI: https://doi.org/10.1002/ jae.659. 
Belke, A.; Dobnik, F.; Dreger, C. (2011). Energy consumption and economic growth: New insights into the cointegration relationship. Energy Economics 33(5): 782789. DOI: https://doi.org/10.1016/j.eneco.2011.02.005.

Benli, M.; Altintas, H.; Kaplan, M. (2019). Asymmetric effect of oil prices on economic growth: Evidence from Turkey. Bilecik Şeyh Edebali University Journal of Social Sciences Institute 4(1): 266-278. DOI: 10.33905/bseusbed.480869.

Constantini, V.; Martini, C. (2010). The causality between energy consumption and economic growth: A multi-sectoral analysis using non-stationary cointegrated panel data. Energy Economics 32(3): 591-603. DOI: https://doi.org/10.1016/j. eneco.2009.09.013.

Dickey, D.; Fuller, W. (1979). Distribution of the estimators for autoregressive time series with a unit root. Journal of American Statistical Association 74(366): 427-431. DOI: https://www.jstor.org/stable/2286348.

Dogan, E. (2015). The relationship between economic growth and electricity consumption from renewable and non-renewable sources: A study of Turkey. Renewable and Sustainable Energy Reviews 52: 534-546. DOI: https://doi. org/10.1016/j.rser.2015.07.130.

Enu, P.; Havi, E. (2014). Influence of electricity consumption on economic growth in Ghana: An econometric approach. International Journal of Economics, Commerce and Management II(9): 1-20.

Esen, O.; Bayrak, M. (2017). Does more energy consumption support economic growth in net energy-importing countries? Journal of Economics, Finance and Administrative Science 42(22): 75-98. DOI: 10.1108/JEFAS-01-2017-0015.

Farzanegan, M. R.; Markwardt, G. (2009). The effects of oil price shocks on the Iranian economy. Energy Economics 31(1): 134-151. DOI: https://doi. org/10.1016/j.eneco.2008.09.003.

Fatai, B. (2014). Energy consumption and economic growth nexus: Panel cointegration and causality tests for Sub-Saharan Africa. Journal of Energy in Southern Africa 25(4): 93-100.

Fatai, K.; Oxley, L.; Scrimgeour, F. G. (2004). Modelling the causal relationship between energy consumption and GDP in New Zealand, Australia, India, Indonesia, the Philippines and Thailand. Mathematics and Computers in Simulation 64(3-4): 431-445. DOI: https://doi.org/10.1016/S0378-4754(03)00109-5.

Ftiti, Z.; Guesmi, K.; Teulon, F.; Chouachi, S. (2016). Relationship between crude oil prices and economic growth in selected OPEC countries. The Journal of Applied Business Research 52(1): 11-22. DOI: https://doi.org/10.19030/jabr.v32i1.9483. International Energy Agency (IEA). (2002). World Energy Outlook: Energy and Poverty. IEA.

Iwayemi, A. (1998). Energy sector development in Africa. A background paper prepared for the African Development Report 1998. Retrieved in: October 2017, from: https:// 
www.afdb.org/fileadmin/uploads/afdb/Documents/Publications/00157620-ENERP-43.PDF.

Iwayemi, A.; Babajide, F. (2011). Impact of oil price shocks on selected macroeconomic variables in Nigeria. Energy Policy 39(2): 603-612. DOI: https://doi.org/10.1016/j. enpol.2010.10.033.

Jafari, Y.; Othman, J.; Nor, A. H. (2012). Energy consumption, economic growth and environmental pollutants in Indonesia. Journal of Policy Modeling 34(6): 879-889.

Jayaraman, T. K.; Choong, C. K. (2009). Growth and oil price: A study of causal relationship in small Pacific Island countries. Energy Policy 37(6): 2182-2189. DOI: https://doi.org/10.1016/j.enpol.2009.01.025.

Kraft, J.; Kraft, A. (1978). On the relationship between energy and GNP. The Journal of Energy and Development 3(2): 401-403. DOI: https://www.jstor.org/ stable/24806805.

Lardic, S.; Mignon, V. (2006). The impact of oil prices on GDP in European countries: An empirical investigation based on asymmetric cointegration. Energy Policy 34(18): 3910-3915. DOI: https://doi.org/10.1016/j.enpol.2005.09.019.

MBendi (2016, 10 October). Electrical Power in Nigeria: Overview. Retrieved from: https://www.mbendi.com/indy/powr/af/ng/p0005.htm.

Mehrara, M. (2008). The asymmetric relationship between oil revenues and economic activities: The case of oil-exporting countries. Energy Policy 36(3): 1164-1168. DOI: https://doi.org/10.1016/j.enpol.2007.11.004.

Nigeria Electricity Regulatory Commission. (2017). Generation: Power generation in Nigeria. Retrieved on: 24 August 2017, from: Nigeria Electricity Regulatory Commission Website: http://nercng.org/index.php/home/nesi/403-generation.

Nwachukwu, J. (2015, 28 April). NEWS ANALYSIS: Appraising the feats of the Jonathan-administration in the power sector. Retrieved on: 23 August 2017, from: The Guardian: https://guardian.ng/news/news-analysis-appraising-thefeats-of-the-jonathan-administration-in-the-power-sector/.

Nwankwo, O. C.; Njogo, B. O. (2013). The effect of electricity supply on industrial production within the Nigerian economy (1970-2010). Journal of Energy Technologies and Policy 3(4): 34-42.

Nwanna, I.; Eyeday, A. (2016). Impact of crude oil price volatility on economic growth in Nigeria (1980-2014). IOSR Journal of Business and Management 18(6): 10-19.

Odularu, G.; Okonkwo, C. (2009). Does energy consumption contribute to economic performance? Empirical evidence from Nigeria. East-West Journal of Economics and Business 12(2): 43-79.

Ogboru, I.; Rivi, M.; Park, I. (2017). The impact of changes in crude oil prices on economic growth in Nigeria: 1985-2015. Journal of Economics and Sustainable Development 8(12): 78-89. 
Omitogun, O.; Longe, A.; Muhammad, S. (2018). The impact of oil price and revenue variations on economic growth in Nigeria. OPEC Energy Review 42(4): 397-402. DOI: https://doi.org/10.1111/opec.12139.

Oyaromade, R.; Mathew, A.; Abalaba, B. (2014). Energy consumption and economic growth in Nigeria: A causality analysis. International Journal of Sustainable Energy and Environmental Research 3(1): 53-61.

Paul, O.; Albert, O.; Adeiza, A. (2015). Electricity crisis in Nigeria: The way forward. American Journal of Renewable and Sustainable Energy 1(4): 180-186.

Pesaran, H. M.; Shin, Y.; Richard, S. J. (2001). Bounds testing approaches to the analysis of level relationships. Journal of Applied Econometrics 16(3): 289-326.

Phillips, P. C. B.; Perron, P. (1988). Testing for a unit root in time series regression. Biomètrika 75: 335-346. DOI: 10.2307/2336182.

Sama, M.; Tah, N. (2016). The effect of energy consumption on economic growth in Cameroon. Asian Economic and Financial Review 6(9): 510-521.

Samu, R.; Bekun, F.; Fahrioglu, M. (2019). Electricity consumption and economic growth nexus in Zimbabwe revisited: Fresh evidence from Maki cointegration. International Journal of Green Energy 16(7): 540-550. DOI: https://doi.org/1 0.1080/15435075.2019.1598417.

Sarwar, S.; Chein, W.; Waheed, R. (2017). Electricity consumption, oil price and economic growth: Global perspective. Renewable and Sustainable Energy Reviews 76: 9-18. DOI: https://doi.org/10.1016/j.rser.2017.03.063.

Shahbaz, M.; Adnan Hye, Q. M.; Tiwari, A. K.; Leitão, N. C. (2013). Economic growth, energy consumption, financial development, international trade and CO2 emissions in Indonesia. Renewable and Sustainable Energy Reviews 25: 109-121. DOI: https://doi.org/10.1016/j.rser.2013.04.009.

Shahbaz, M.; Dube, S. (2012). Revisiting the relationship between coal consumption and economic growth: Cointegration and causality analysis in Pakistan. Applied Econometrics and International Development 12(1): 166-192.

Shahbaz, M.; Hoang, T. H.; Mahalik, M. K.; Roubaud, D. (2017). Energy consumption, financial development and economic growth in India: New evidence from a nonlinear and asymmetric analysis. Energy Economics 63: 199-212. DOI: https:// doi.org/10.1016/j.eneco.2017.01.023.

Shahbaz, M.; Lean, H. (2012). Does financial development increase energy consumption? The role of industrialization and urbanization in Tunisia. Energy Policy 40: 473-479. DOI: https://doi.org/10.1016/j.enpol.2011.10.050.

Shahbaz, M.; Sarwar, S.; Chein, W.; Malik, M. N. (2017). Dynamics of electricity consumption, oil price and economic growth: Global perspective. Energy Policy 108: 256-270. DOI: https://doi.org/10.1016/j.enpol.2017.06.006.

Shahbaz, M.; Tang, C. F.; Shabbir, M. S. (2011). Electricity consumption and economic growth nexus in Portugal using cointegration and causality approaches. Energy Policy 39(6): 3529-3536. DOI: https://doi.org/10.1016/j.enpol.2011.03.052. 
Shahbaz, M.; Tiwari, A. K.; Nasir, M. (2013). The effects of financial development, economic growth, coal consumption and trade openness on CO2 emissions in South Africa. Energy Policy 61: 1452-1459. DOI: https://doi.org/10.1016/j. enpol.2013.07.006.

Shin, Y.; Yu, B.; Greenwood-Nimmo, M. J. (2014). Modelling asymmetric cointegration and dynamic multipliers in a nonlinear ARDL framework. In: William, C. H.; Robin, C. S. (eds.), Festschrift in honor of Peter Schmidt: Econometric methods. New York: Springer Science \& Business Media. 281-314. DOI: https://doi.org/10.1007/978-14899-8008-3_9.

Squalli, J. (2007). Electricity consumption and economic growth: Bounds and causality analyses. Energy Economics 29(6): 1192-1205. DOI: https://doi. org/10.1016/j.eneco.2006.10.001.

Thoma, M. (2004). Electrical energy usage over the business cycle. Energy Economics 26(3): 463-485.

Timilsina, G. R. (2015). Oil prices and the global economy: A general equilibrium analysis. Energy Economics 49: 669-675. DOI: https://doi.org/10.1016/j. eneco.2015.03.005.

Wolde-Rufae, Y. (2006). Electricity consumption and economic growth: A time series experience for 17 African countries. Energy Policy 34(10): 1106-1114. DOI: https://doi.org/10.1016/j.enpol.2004.10.008.

Yakubu, M.; Akanegbu, B. (2019). Oil price volatility and economic growth in Nigeria. Advances in Management \& Applied Economics 9(6): 1-10. 